\title{
Perilaku Masyarakat dalam Menghadapi Dampak Kesehatan Akibat Bencana Banjir di Desa Lubuk Siam, Kabupaten Kampar, Riau
}

\author{
Gebrina Reski, ${ }^{1 *}$ Zahtamal $^{2}$
}

\begin{abstract}
Riau Province is one of the areas in Indonesia that is prone to flooding, one of which is in the village of Lubuk Siam, Siak Hulu District, Kampar Regency. Flood conditions that have a negative impact are often caused by the low behavior of the community. The purpose of this study was to determine the behavior of the community in dealing with the health impacts of the flood disaster. This type of research is descriptive qualitative with a phenomenological approach. This research was conducted in Lubuk Siam Village, Siak Hulu District, Kampar Regency, Riau Province. The informants in this study were 16 participant consisting of the community, the village head and staff, representatives of the puskesmas, community leaders and youth leaders who were obtained by purposive sampling technique. The data in this study were analyzed by content analysis. Data collection uses focus group discussions, in-depth interviews, and observations. The results of this study obtained that community behavior in dealing with health impacts due to flooding is still not ideal, some efforts to prevent health impacts and flood disaster management have been good and some have not. In terms of preparedness to face floods, the community has not as a whole prepared evacuation facilities during floods, logistics and medicines as first aid during floods. Treatment efforts if there are family members who experience health effects are still not optimal. Treatment efforts seem to be meager.
\end{abstract}

Keywords: flood, health impact, community behavior

Banjir merupakan peristiwa naiknya air menggenangi suatu wilayah yang biasanya tidak digenangi air dalam jangka waktu tertentu. ${ }^{1}$ Banjir disebabkan oleh kondisi alam seperti curah hujan yang tinggi, amblesan dan pendangkalan sungai, serta aktivitas manusia. ${ }^{2}$ Indonesia saatini memiliki pola curah hujan yang lebih pendek namun dengan intensitas tinggi, hal ini mengakibatkan peningkatan risiko terjadinya banjir saat musim hujan.

Provinsi Riau merupakan salah satu daerah rawan bencana banjir, hampir setiap tahunnya ketika datang musim penghujan maka akan terjadi banjir di beberapa daerah Riau. Jumlah kejadian banjir di Riau 6 tahun terakhir mengalami peningkatan yaitu 12 kejadian di tahun 2014, 9 kejadian tahun 2015, 10 kejadian tahun 2016, 17 kejadian tahun 2017, 15 kejadian tahun 2018 dan

\footnotetext{
* Penulis Korespondensi : riskigebrina@gmail.com

1 Program Studi Kedokteran Fakultas Kedokteran Universitas Riau, Pekanbaru, Riau, Indonesia

2 KJFD Ilmu Kesehatan Masyarakat Fakultas Kedokteran Universitas Riau, Pekanbaru, Riau Indonesia
}

tahun 2019 berjumlah 16 kejadian. Selanjutnya, berdasarkan data Badan Penanggulangan Bencana Daerah (BPBD) Provinsi Riau pada tahun 2019 terdapat 5 kabupaten yang mengalami bencana banjir, yaitu Kabupaten Kampar, Kabupaten Rokan Hulu, Kabupaten Rokan Hilir, Kabupaten Indragiri Hulu, dan Kabupaten Kuantan Singingi. Kabupaten dengan luas daerah dan korban terdampak banjir terbesar adalah Kabupaten Kampar. Salah satu desa yang terkena dampak terbanyak yakni Desa Lubuk Siam.

Desa Lubuk Siam merupakan desa yang memiliki kondisi geografis ketinggian tanah hanya $15 \mathrm{~m}$ dari permukaan laut dan terletak memanjang sejajar Sungai Kampar yang mengalir dari Barat ke timur. Karena letaknya yang rendah dan berada di pinggir sungai Kampar menyebabkan risiko terkena bencana banjir pun meningkat. Banjir yang terjadi hampir setiap tahun di Desa Lubuk Siam menyebabkan dampak yang begitu besar bagi masyarakat. $^{3}$

Bencana banjir menimbulkan dampak sangat besar termasuk terhadap ekonomi, menurunnya 
kualitas hidup penduduk, dan kesehatan. Bencana banjir umumnya berlangsung lama sehingga menyebabkan kerusakan sistem sanitasi, air bersih serta dapat menimbulkan potensi Kejadian Luar Biasa (KLB), penyakit yang ditularkan melalui media air (water-borne disease) seperti diare dan leptospirosis. ${ }^{4,5}$

Besarnya dampak kesehatan yang ditimbulkan akibat bencana banjir, diperlukan kesiapsiagaan banyak aspek dan pihak yang terlibat, termasuk pelayanan kesehatan dan masyarakat. ${ }^{6}$ Strategi umum dapat diterapkan dalam penyelenggaraan penanggulangan bencana yang meliputi kegiatan tahap prabencana, saat tanggap darurat, maupun pasca bencana. ${ }^{2}$

Masyarakat diharapkan berperan penting dalam melakukan pencegahan dan penanggulangan bencana banjir. Masyarakat harus memiliki pengetahuan dan sikap yang positif serta diperlukan praktik dalam pencegahan dan penanggulangan bencana banjir. Dengan ketersediaan pengetahuan dan sikap yang cukup maka akan terbentuknya tindakan sehingga timbullah perilaku yang baik dalam penanggulangan banjir. Semakin tinggi pengetahuan seseorang maka perilaku kesiapsiagaannya juga akan meningkat. ${ }^{7}$

Penelitian di Bolapapu Kecamatan Kulawi Sigi Sulawesi Tengah mendapatkan bahwa kesiapsiagaan masyarakat masih kurang. Kesiapsiagaan yang kurang ini disebabkan oleh kurangnya pengetahuan masyarakat sehingga memengaruhi sikap dan tindakan masyarakat. Masyarakat daerah tersebut bahkan kurang mengetahui tentang banjir dan persiapan yang dipersiapkan ketika banjir. ${ }^{8}$

Sampai saat ini, kajian perilaku masyarakat dalam menghadapi dampak kesehatan akibat bencana banjir khususnya di Provinsi Riau masih jarang dilakukan. Sehingga kajian ini akan memberikan referensi, jika akan melakukan pengembangan upaya pencegahan, pengendalian,dan kesiapsiagaan menghadapi bencana banjir terutama untuk masyarakat di desa rawan bencana secara khusus Desa Lubuk Siam dan masyarakat Riau secara umum.

\section{METODE}

Penelitian ini merupakan penelitian deskriptif kualitatif dengan pendekatan fenomenologi untuk mengetahui gambaran perilaku masyarakat dalam menghadapi dampak kesehatan akibat bencana banjir di Desa Lubuk Siam Kecamatan Siak Hulu Kabupaten Kampar Provinsi Riau.

Penelitian ini dilakukan di Desa Lubuk Siam Kecamatan Siak Hulu Kabupaten Kampar Provinsi Riau. Informan dalam penelitian ini berjumlah 16 orang dengan informan utama berjumlah 7 orang, informan kunci berjumlah 7 orang dan informan pendukung berjumlah 2 orang. Informan dalam penelitian ini terdiri dari masyarakat, kepala desa beserta staff, perwakilan puskesmas, tokoh masyarakat dan ketua pemuda yang didapatkan dengan teknik purposive sampling. Pengumpulan data menggunakan Focus group discussion, wawancara mendalam, dan observasi. Dianalisis melalui konten analisis dengan menggunakan metode triangulasi.

\section{HASIL}

Banjir yang hampir setiap tahun terjadi di Desa Lubuk Siam mempengaruhi perilaku masyarakat dalam penanggulangan bencana banjir terutama dibidang kesehatan. Beberapa kegiatan masyarakat dalam penanggulangan banjir sebelum, saat dan sesudah banjir melanda yaitu melakukan persiapan mulai pakan, sandang, pangan, dan keuangan. Keadaan desa yang berada di tepi sungai Kampar dan sering menjadi sasaran banjir membuat masyarakat sudah terbiasa dan merasa pasrah karna bencana tersebut atas kuasa dari Tuhan yang Maha Esa. Masyarakat menganggap banjir merupakan hal yang biasa karena hampir setiap tahun terjadi banjir di Desa Lubuk Siam. Sesuai dengan pernyataan dari pihak kepala desa dan masyarakat berikut:

"Bagi masyarakat kita banjir ni biasa aja.. banjir tu memang musibah, tanaman mati, langkah terhalang, anak sekolah gak bisa, ..."(Informan $\mathrm{K} 8$ ).

"kalau bagi saya sendiri kalau banjir tu memang musibah, tanaman mati, langkah terhalang, anak sekolah gak bisa"(Informan K1). 
Secara umum masyarakat sudah memahami kondisi banjir yang terjadi di desa nya. Banjir disebabkan murni karena bencana alam dan bukan ulah manusia, seperti membuang sampah ke sungai atau penebangan pohon di sepanjang aliran sungai. Sesuai dengan pernyataan masyarakat dan kepala desa berikut:

"Ya kalau hujan terus di kampung sini pasti banjir, tu disebabkan bencana murni" (Informan $\mathrm{K} 2$ ).

" penyebabnya kami dimusim hujan, musim hujan itu akibatnya pertama dari PLTA dari koto Kampar, ya kalau sumbar itu udah meluap, PLTA itu pintu baru buka. .Karena kita jalur sungai Kampar.di Kampar itu 75 desa yang aliran sungai Kampar yang dampaknya, kalau Siak Hulu ini termasuk desa Lubuk Siam dampak banjirnya, iyaa curah hujan.

Terkait dengan aktivitas masyarakat ketika banjir atau aktivitas dalam menghadapi banjir, masyarakat sudah melakukan persiapan sebelum terjadinya banjir. Masyarakat melakukan persiapan mulai dari sarana prasarana ketika banjir maupun keperluan yang dibutuhkan saat banjir. Sesuai Pernyataan pihak kepala desa berikut:

"Kan disini banjir nya bukan seperti daerah lain, kita misalnya kalau mau lari bisa atau mau pindah bisa, tidak buru buru gitu. Kayak di kota kota hujan langsung banjir langsung masuk kerumah. Kalau ini ndak paling 3 hari baru naiknya segini" (Informan K9).

Terkait dengan dampak kesehatan akibat bencana banjir, masyarakat mengatakan keluhan yang sering dialaminya adalah beberapa penyakit seperti diare, demam, influenza dan gatal-gatal. Sesuai dengan pernyataan masyarakat berikut:

"Pas banjir mungkin ada ..tapi biasanya habis banjir tu domam, batuk, anak anak yang banyak biasanya setelah banjir, kumbuo ayi (istilah lokal untuk penyakit yang dialami masyarakat setempat setelah banjir); gejala demam, gatal gatal, kumbuo tu artinya penyakit yang timbul karna air gejalanyo penyakit kulit, domam, sakit mato,mencret, itu penyakitnyo"(Informan K1).

Masyarakat setempat mengganggap keluhan kesehatan yang dinamakan "kumbuo ayi" tersebut dipercaya sebagai akibat/karna banjir bukan karena kutukan. Akan tetapi ada juga yang berpersepsi akibat adanya pengaruh dari makhluk jin (bahasa local/setempat: hantu) sehingga pengobatan dilakukan ada yang diobati sendiri/ke dukun dan ada juga ke petugas kesehatan. Kepercayaan masyarakat terhadap penyakit tersebut membuat sebagian masyarakat melakukan pengobatan tradisional dan sebagian masyarakat juga melakukan pengobatan ke petugas kesehatan. Sesuai dengan pernyataan masyarakat berikut:

"Pengobatan tradisional tu ada dikasih kelapa, kunyit, kelapa muda tu untuk nurunkan panas, Kalau penanganan pertamo kalau ado anak domam, kalau disiko dibuek dari kunyik pak"(Informan K5).

Berdasarkan laporan penyakit dari Puskesmas, angka kejadian penyakit terbanyak yaitu diare. Masyarakat mengeluhkan terserang penyakit seperti penyakit kulit, diare dan demam yang juga disebabkan oleh sanitasi dan kondisi lingkungan yang penuh dengan air saat banjir. Untuk pengobatan masyarakat berkoordinasi dengan pihak kesehatan atau pihak puskesmas pembantu

yang bertugas mengkoordinasi apabila ada masyarakat yang terjangkit penyakit akan segera ditindaklanjuti dan segera diobati.

Bentuk perilaku masyarakat dalam upaya pencegahan dan penanggulangan bencana banjir yaitu dengan melakukan gotong royong sebelum dan sesudah terjadinya banjir.

"Bersih bersih, bikin panggung, jemuran ditinggikan, kalau banjir masuk ke dalam rumah banyak dari kayu panggung kadang ada pakai drum. Kalau kami udah dipersiapkan pentasnya, jadi kalau datang banjir tinggal ngerakit pasang pentas"'(Informan K4).

"orang orang juga kadang dah nyiapkan panggung panggung kayu kayu untuk pangken. pas banjir aja"(Informan K9).

Upaya pencegahan dan penanggulangan banjir yang sudah dan belum direncanakan serta dikerjakan oleh pihak kepala desa dan jajarannya terungkap dari pernyataan pihak desa berikut:

"Mungkin kebijakan kami tahun ini kami sudah membuat posko kebanjiran ada dua tempat tahun 2020 mungkin sudah dilaksanakan. 
Dusun 2 dan dusun 3 udah ditinjau kemaren dari perencanaan "(Informan K8).

Pelayanan kesehatan sangat diperlukan masyarakat ketika banjir. Masalah pelayanan kesehatan saat banjir meliputi peran petugas kesehatan dan hambatan ke pelayanan kesehatan. Sesuai dengan pernyataan masyarakat berikut:

"kalau kami biasanya waktu banjir sakit warga kita kami sudah berkoordinasi dengan pak KAPUS(kepala Pustu), sakitnya berapa orang pak nantik pengobatannya kami nantik dikirim itu bukan langsung kedesa, langsung kami pergi orang Pustu, orang bidan, nantik masyarakat itu langsung kerumah Pustu' (Informan K5).

Ketika banjir, saat sakit bertambah parah dan tidak memungkinkan tetap tinggal di rumah, respon rata-rata keluarga cukup bervariasi. Masyarakat akan melapor ke tenaga kesehatan. Untuk masyarakat yang diharuskan untuk mengungsi biasanya masyarakat akan mengungsi ke posko terdekat sesuai dengan pernyataan dari kepala desa berikut: $\mathrm{K} 8$ ).

“melapor ke bidan puskesmas aja” (Informan

"oo kadang kami ngungsi, mengungsi ke posko..dusun satu posko 1, dusun 2 posko 2, tiap dusun satu poskonya. Dusun ompek di mushalla, dusun tigo dimushalla, kadang tempat tu tinggi jadi gak kena" (Informan K1).

Terkait dengan adanya anggota keluarga yang rentan terkena dampak banjir terutama dampak kesehatan seperti bayi, anak-anak, ibu hamil dan lansia hal yang dilakukan oleh masyarakat yaitu dengan berkoordinasi dengan pihak kesehatan terutama puskesmas untuk evakuasi jika ada masyarakat yang harus dievakuasi. Sesuai pernyataan dari kepala desa berikut:

"Wajib ada sampan, ada dari tim tim yang ada perahu, pakai pompong, nantik ada orang kesehatan kasih tau kalau sakit dijemput orang $t u$ "(Informan K8)

Pihak desa dalam melakukan evakuasi masyarakat yang rentan terkena dampak kesehatan akan dievakuasi apabila ada laporan dari masing masing masyarakat. Masyarakat yang tidak wajib dievakuasi dan masih bisa dirawat dirumah maka pihak desa akan berkoordinasi dengan pihak kesehatan dalam menangani masyarakat tersebut dengan datang ke rumah dan memeriksa serta memberikan perawatan kepada masyarakat tersebut. Tenaga kesehatan akan melakukan pengecekan dan memberikan obat obatan sesuai keluhan. Sesuai pernyataan dari pihak kepala desa berikut:

"Terkait evakuasi... kita dapat laporan, disini memang sudah kita umumkan.. memang jika tidak bagus lagi dirumah, tidak sesuai harus kita ungsikanlah keluar tapi mereka gak mau pak tetap bertahan dirumah masing masing, tetap dirumah tergantung kondisi, nantik telfon bidan, perawat suruh datang kerumah untuk ngasih obat cek tensi cek inilah segala macam itu aja" (Informan K9).

Upaya yang dilakukan apabila ada warga yang terkena penyakit dan harus dilakukan perawatan . Pihak desa melakukan kerjasama dengan pihak kepala desa, tenaga kesehatan. sesuai dengan pernyataan pihak desa berikut:

"Tidak ada yang mengungsi, tetap dirumah masing masing. ..., bertahan dirumah masing masing"(Informan K14).

Cuma koordinasi RT pak kades itu didusun 3 ada yang sakit kami turun, kami cek sama perawat desa sama bidan kalau memang ini harus kita bawa keluar ya kami bawa keluar"(Informan K9).

Terkait dengan kepemilikan peralatan penyelamatan dan evakuasi sederhana selama banjir diketahui bahwa kepemilikan sarana di masyarakat menggunakan sarana transportasi berupa sampan dan dari tim sar. Sesuai dengan pernyataan kepala desa berikut:

"Pelampung ndak ada, yang ada sampan, terus yang dari tim sar sudah menyiapkan kalau sedang banjir" (Informan K9).

"Jalur evakuasi sendiri belum ada, tapi dulu emang ada pak dari dinas kabupaten sejenis plank, ini rawan banjir itu ada dari Kampar, Kalau jalur evakuasi kan orang kita udah tahu rata rata orang setempat"'(Informan K9).

Sarana atau penyimpanan logistik di bidang kesehatan yang disiapkan oleh masyarakat saat banjir berupa obat obatan. . Sebagian masyarakat mempersiapkan obat obatan selama banjir namun 
sebagian masyarakat yang tidak mempersiapkan obat obatan dirumah pergi ke pustu terdekat. Obat obatan yang biasa dipersiapkan seperti obat demam, obat flu, dan sebagian warga juga mempersiapkan vitamin. Sesuai dengan pernyataan masyarakat berikut:

"Makanan dan obat distok dirumah, kadang kadang ada kadang kadang tidak, obat demam, paling beli di warung. Kalau banjir kami kan pakai sampan ke puskesmas, pustu kan ada pustunya, jaga kebersihan, siapkan obat, obat mencret, obat domam, ubek batuk, dan ada yang gak stok dirumah pergi ke posko minta obat, ndak semua warga menyiapkan" (Informan K1).

Selama bencana banjir, rata-rata perilaku keluarga menggunakan air bersih untuk keperluan masak, dan keperluan MCK (Mandi, Cuci dan Kakus, gosok gigi). Akan tetapi ada juga masyarakat yang membeli sendiri air bersih untuk sarana MCK. Sesuai dengan pernyataan masyarakat berikut:

"Ya pakai air banjir, untuk nyuci air segala macamnya. Kan banyak yang menggunakan air banjir". (Informan K5).

"Hampir 70\% menggunakan air banjir untuk mandi, minum dan semuanya tadi tu. Yang mampu beli air bersih diluar sekitar 30\%"(Informan K3).

"Iya dari luar, dibeli pergalon 3.500.. beda beda ada yang 8000 perjerigen" (Informan K2).

Penggunaan air bersih yang disampaikan oleh masyarakat sesuai dengan pernyataan dari pihak kepala desa. Sebagian besar masyarakat masih mengeluhkan kekurangan air bersih dan

logistic ketika banjir karena susahnya akses air bersih. Sesuai dengan pernyataan masyarakat berikut:

"Selama banjir logistic dan bahan makanan kendala semuanya kurang, mulai dari konsumsi makanan, air bersih kurang"(Informan K8).

Ketersedian posko kesehatan dalam menyediakan obat obatan dan peran tenaga kesehatan untuk menghadapi dampak kesehatan yang ditimbulkan akibat banjir sudah lumayan mencukupi, namun untuk akses masyarakat ke posko kesehatan masih terbatas. Sesuai dengan pernyataan kepala desa berikut:
"Ada yang dari dusun 4 tu jauh, dari mereka tu kesini kadang terbatas kadang ada sampan mereka kadang ada orang bawa, kadang terpaksa orang pustu ni kerumah beliau. Mereka mengeluh karena poskonya cuman satu. Dusun satu kadang juga melewati kesini ya terpaksa terbataslah" (Informan K9).

Dalam melakukan persiapan ketika menghadapi masalah kesehatan yang timbul akibat banjir diperlukannya pelatihan atau sosialisasi dari tenaga kesehatan dalam mengedukasi masyarakat, namun di Desa Lubuk Siam sendiri masih kurang dalam sosialisasi dampak kesehatan dan persiapan yang harus disiapkan ketika banjir. Seperti pernyataan dari pihak desa berikut:

"gak ada, belum kami laksanakan, tapi setiap hari kami kedusun masing masing pakai sampan trus kalau anak anak jangan mandi mandi seperti itu aja"(Informan K9).

Masyarakat Desa Lubuk Siam juga merealisasikan perilaku aman selama banjir dengan membuat instalasi atau tali listrik diposisi tinggi sehingga dapat mengurangi resiko yang tidak diinginkan selama banjir.

"Arus listrik tetap jalan, kadang nonton kami. Cuma waspada hati hati, makonyo tali listrik atau instalasi tinggi kalau disiko" (Informan K1).

Harapan masyarakat secara umum dalam dalam upaya pencegahan dan penanggulangan bencana banjir antara lain adalah peningkatan layanan kesehatan.

"Persediaan obat dirumah, lengkapi kalau ada dana obat obat dilengkapi, minta lebih ditingkatkan lagi pelayanannya disaat banjir, seperti pelayanan gratis dan dikasih obat banjir untuk warga, maksudnya pas banjir tu datangnya Cuma 2 sampai 3 kali jadi ditingkatkanlah lagi, saat banjir, setelah banjir masih ada petugas kesehatannya" (Informan K2).

Dalam menghadapi dampak kesehatan akibat banjir, pihak desa bekerjasama dengan dinas kesehatan dan pemerintahan. Kegiatan yang dilakukan masyarakat untuk mengatasi banjir mulai dari penanggulangan bencana banjir sebelum, saat maupun sesudah banjir dapat dilihat dari pernyataan berikut: 


\section{"koordinasi dengan pihak terkait seperti dinas kesehatan terus BPBD,dinas sosial"(Informan K9).}

"Kegiatan khusus untuk mengatasi banjir tu tidak ada, tapi untuk mengatasi tebing pinggir sungai tu ada seperti turap untuk penahan tebing supaya tidak runtuh sehingga rumah masyarakat tidak runtuh seperti itu aja dari APBN. Kegiatan di desa untuk mengatasi masalah

banjir/ bencana mulai pencegahan dan penanggulangan banjir tidak ada, cuma koordinasi sama kerja sama aja, gotong royong"(Informan $\mathrm{K} 8$ ).

Ketersediaan sarana dan prasarana di desa untuk pencegahan dan penanggulangan banjir khususnya dalam mengurangi dampak kesehatan kepada masyarakat yaitu dengan menyediakan ambulance desa dan penyediaan posko, dapur umum dan obat obatan.

"Alat untuk persiapan banjir tadi ambulance desa, kan bagi masyarakat betul betul miskin itu datang kerumah kepala desa nantik posko dapur yang sudah kami tentukan itu posko atau kantor kantor desa ni kami stand by sini, kalau betul betul susah kami kasih nantik nahan makanan" (Informan K8).

Harapan pihak kepala desa secara umum dalam dalam upaya pencegahan dan penanggulangan dampak kesehatan akibat bencana banjir antara lain adalah kelengkapan sarana prasarana serta peningkatan layanan kesehatan. Masyarakat masih merasa kekurangan logistik atau sarana kesehatan ketika banjir dan penyediaan air bersih yang masih kurang.

"Dari desa kami butuh seperti oksigen stand by, karena mengantisipasi ke puskesmas tu ke rumah sakit tu ....kita perlu, alat alat kesehatan yang kita perlu, untuk obat obatan cukup. Infus dan yang butuh sekali adalah penysediaan air bersih" (Informan K8).

\section{PEMBAHASAN}

Berdasarkan hasil penelitian yang telah dilakukan dapat diketahui bahwa masyarakat Desa Lubuk Siam secara umum sudah memahami kondisi banjir yang terjadi di desanya, baik penyebab maupun dampak yang ditimbulkan. Kejadian banjir memberi dampak terhadap masyarakat baik dampak ekonomi, lingkungan, maupun dampak kesehatan. Bencana tidak hanya menimbulkan korban jiwa dan luka serta rusaknya berbagai fasilitas kesehatan, tetapi juga

berdampak pada permasalahan kesehatan masyarakat, seperti munculnya berbagai penyakit setelah banjir, fasilitas air bersih yang kurang memadai dan sanitasi lingkungan yang kurang baik. Dampak banjir terhadap kesehatan dapat menyebabkan timbulnya berbagai penyakit pada masyarakat baik anak anak maupun orang dewasa. ${ }^{9}$

Pengetahuan merupakan dasar bagi seseorang untuk melakukan upaya penanggulangan dan kesiapsiagaan dalam menghadapi banjir terutama tentang dampak banjir terhadap kesehatan dan tindakan untuk menghindari dampak yang ditimbulkan. Pengetahuan dipengaruhi oleh pengalaman seseorang dalam menghadapi suatu kejadian dilingkungannya. Pengalaman dan lingkungan yang dipersepsikan oleh seseorang menimbulkan keinginan untuk bertindak. Semakin tinggi pengetahuan seseorang maka semakin tinggi juga kemampuan seseorang tersebut dalam melakukan penilaian terhadap suatu objek. Penilaian ini bermanfaat sebagai landasan seseorang untuk bertindak atau melakukan praktik. ${ }^{10}$

Pada penelitian ini didapatkan masyarakat Lubuk Siam sudah memahami dan mengetahui kondisi banjir yang terjadi di desanya, baik dari penyebab dan dampak yang akan ditimbulkan secara umum karena masyarakat telah memiliki banyak pengalaman dalam menghadapi bencana banjir selama tinggal di daerah tersebut sehingga dapat belajar dari pengalaman. ${ }^{11}$ Namun, untuk persiapan dalam menghadapi bencana banjir terutama dampak kesehatan masih kurang. Masyarakat masih kurang memahami mengenai penggunaan air bersih, persiapan obat obatan, dan P3K. Hal ini menyebabkan masyarakat malah terkesan menganggap banjir sudah menjadi hal yang biasa dan tidak perlu dikhawatirkan.

Pengetahuan yang kurang mengenai persiapan banjir akan mempengaruhi kesiapsiagaan masyarakat sebaliknya semakin banyak pengetahuan yang didapatkan akan mempengaruhi persiapan masyarakat dalam menghadapi dampak 
kesehatan akibat bencana banjir. Hal ini

sejalan dengan penelitian di Kelurahan Gondrong Kota Tangerang bahwa responden yang berpengetahuan tinggi memiliki kesiapsiagaan yang siap artinya ada hubungan antara pengetahuan dengan kesiapsiagaan, orang berpengetahuan tinggi memiliki kesiapsiapsiagaan 4 kali dari orang yang berpengetahuan kurang, artinya masyarakat lebih siap dalam mempersiapkan hal hal yang diperlukan sebelum, saat dan setelah banjir. ${ }^{12}$

Masalah kesehatan yang timbul akibat bencana banjir antara lain berawal dari kurangnya air bersih yang berakibat pada buruknya kebersihan diri, buruknya sanitasi lingkungan dan merupakan awal dari perkembangbiakan beberapa jenis penyakit menular. Persediaan pangan yang tidak mencukupi juga merupakan awal dari proses terjadinya penurunan derajat kesehatan yang dalam jangka panjang akan mempengaruhi secara langsung tingkat pemenuhan kebutuhan gizi korban bencana. ${ }^{13}$

Informasi dari hasil penelitian didapatkan penyakit yang sering timbul ketika banjir yaitu diare, penyakit kulit, demam. Penyakit yang timbul disebabkan oleh faktor kondisi lingkungan ketika banjir. Sejalan dengan data riskesdas tahun 2018 yang menunjukkan bahwa ketersediaan sumber air minum dan air bersih memengaruhi kasus diare. Sumber air yang tidak memenuhi syarat, yaitu berasa dan terkadang tercium bau menyebabkan diare. Kemudahan mendapatkan air bersih berpengaruh pada kejadian diare balita. Balita yang tinggal di daerah sulit air punya risiko menderita diare 1,2 kali lebih besar dibandingkan balita di daerah yang lebih mudah mendapatkan air bersih. ${ }^{14}$

Bentuk adaptasi masyarakat dalam fase kesiapsiagaan bencana di bidang air bersih sudah berjalan dengan baik. Namun demikian masih terdapat kesenjangan karena perbedaan kemampuan ekonomi, dimana masyarakat yang memiliki ekonomi lebih akan mampu membeli

air bersih dari luar dan sebagian masyarakat yang kurang mampu akan lebih memilih menggunakan air seadanya seperti menampung air hujan maupun air sumur.

Kondisi sanitasi yang buruk saat banjir dapat mempermudah penyebaran penyakit gangguan saluran cerna karena bakteri, virus, jamur dan parasit melalui makanan dan minuman yang dikonsumsi masyarakat. Dalam hal ini, kemungkinan masyarakat belum mendapatkan informasi yang cukup mengenai penyakit-penyakit yang ditimbulkan setelah terjadi banjir. Penyakitpenyakit tersebut dapat timbul karena sistem sanitasi yang tercemar ataupun akibat makanan tercemar air yang telah terkontaminasi air banjir. ${ }^{15}$

Peran semua pihak dalam menghadapi dampak kesehatan yang ditimbulkan oleh banjir diperlukan kerjasama antara masyarakat, pemerintah, kepala daerah, dan tenaga kesehatan. masyarakat memerlukan pelatihan dan sosialisasi terkait dampak banjir di daerahnya. Dalam penelitian ini diketahui masih kurangnya sosialisasi baik dari pemerintah maupun tenaga kesehatan mengenai dampak kesehatan yang ditimbulkan banjir dan penanganannya. Hal ini sejalan dengan penelitian yang telah dilakukan di Kecamatan Barabai Kabupaten Hulu Sungai Tengah dapat disimpulkan bahwa pada pra bencana yang dilakukan di Kecamatan Barabai kurang adanya sosialisasi yang diberikan oleh pihak instansi kepada masyarakat dan kurangnya pelatihan terkait menghadapi banjir sehingga belum adanya peran yang lebih aktif dari pemerintah maupun masyarakat. ${ }^{16}$

Sikap masyarakat dalam menghadapi banjir sangat bervariasi karena setiap orang atau keluarga memiliki pengalaman dan situasi yang berbeda, sehingga dalam menghadapi banjir masingmasing memiliki perilaku yang berbeda pula. Seringkali perilaku tersebut juga dipengaruhi oleh nilai budaya serta kearifan lokal setempat. Dalam penelitian ini didapatkan sikap masyarakat yang terkesan menganggap banjir merupakan hal yang biasa saja karena terjadi hampir tiap tahun sehingga masyarakat merasa sudah terbiasa. Namun, untuk praktik sosial masyarakat untuk berpartisipasi aktif dalam penanggulangan bencana banjir seperti bergotong royong bersama setelah banjir untuk membersihkan lingkungan yang terdampak sudah ada. Hal ini sejalan dengan penelitian yang dilakukan di Lampung didapatkan sikap sosial dan perilaku masyarakat cukup tinggi dalam menghadapi banjir. ${ }^{17}$

Berbagai upaya pemeliharaan kesehatan dan pencegahan sudah dilakukan oleh petugas 
kesehatan pada korban banjir saat banjir. Penelitian ini di dukung oleh penelitian yang dilakukan di Kelurahan Bandarharjo Kota Semarang menunjukan bahwa gambaran aspek kesehatan meliputi jenis pelayanan kesehatan yang dimanfaatkan oleh responden ketika sakit adalah puskesmas (91,3\%), sebanyak 63 responden mengatakan memiliki asuransi kesehatan dimana mayoritas memiliki BPJS (60,9\%). ${ }^{18}$ Mayoritas masyarakat memilih puskesmas yang dimanfaatkan ketika sakit, sehingga peran petugas kesehatan sangat diperlukan oleh korban banjir.

Peran petugas kesehatan pada saat bencana diantaranya melakukan penilaian cepat kesehatan, memberikan pelayanan kesehatan (memberikan pertolongan pertama dan melakukan pemeriksaan kesehatan), mengirimkan perbekalan kesehatan ke lokasi, mengaktifkan unit pelayanan kesehatan dan membuat pos kesehatan dilokasi. ${ }^{19}$ Selain itu, penyuluhan kesehatan juga perlu dilakukan oleh petugas kesehatan, guna untuk meningkatkan pengetahuan dan kesadaran pada korban banjir. ${ }^{20}$

Penyuluhan kesehatan termasuk dalam tindakan promotif yang bertujuan untuk meningkatkan pengetahuan dan kesadaran masyarakat untuk melakukan Perilaku Hidup Bersih dan Sehat (PHBS). ${ }^{21}$ Hasil penelitian ini menunjukkan masih kurangnya masyarakat yang mendapatkan penyuluhan kesehatan. Hal ini dapat menunjukan tingkat pengetahuan dan kesadaran tentang perilaku hidup bersih dan sehat masih kurang. Program tersebut perlu

ditingkatkan lagi guna menyadarkan pentingnya mengupayakan Perilaku Hidup Bersih dan Sehat (PHBS).

Penyuluhan dan praktik PHBS guna mewujudkan masyarakat desa peduli sehat dan penyuluhan ini dapat disosialisasikan serta diterapkan dalam kehidupan sehari hari masyarakat secara kontinyu. ${ }^{22}$ Selain itu, semakin lama air genangan banjir maka akan makin susah melakukan aktivitas termasuk dampak buruk terhadap kesehatan. Individu tidak bisa pergi berobat karena banjir dan jalan-jalan utama susah diakses. Selain itu jarak ke pelayanan kesehatan dipenelitian ini lumayan jauh, sehingga alasan tersebut dijadikan masyarakat enggan pergi berobat dan lebih memilih membiarkan saja atau menunggu ada pemeriksaan gratis di lokasi tersebut. Kunjungan oleh pihak kesehatan dilakukan hanya beberapa kali dalam seminggu.

Masyarakat memanfaatkan fasilitas pengobatan gratis dari puskesmas. Hal inilah yang mempengaruhi partisipan yang lebih banyak memilih pengobatan modern daripada pengobatan tradisional karena pengobatan ini tidak membutuhkan biaya dan sarana transportasi untuk menjangkau tempat pengobatan. Sementara pengobatan yang dilakukan oleh sebagian kecil masyarakat adalah memanfaatkan pengobatan yang telah dilakukan secara turun menurun.

Pada penelitian ini persiapan pengobatan yang dilakukan terdiri dari pengobatan modern dan pengobatan kombinasi (modern dan tradisional). Penelitian ini menunjukkan bahwa sebagian besar masyarakat memilih pengobatan modern sedangkan sebagian lain memilih pengobatan tradisional seperti ke orang biasa bukan ke tenaga kesehatan. Pengobatan modern atau medis merupakan cara yang dilakukan masyarakat dalam upaya penyembuhan, pencegahandan pemulihan penyakit dengan menggunakan produk atau alat. Hal ini tidak sejalan dengan penelitian di Bantul bahwa Masih banyak masyarakat yang mengobati dirinya sendiri di rumah. ${ }^{19}$

Terkait adanya anggota keluarga yang rentan terkena dampak banjir terutama dampak kesehatan seperti bayi, anak-anak, ibu hamil dan lansia hal yang dilakukan oleh masyarakat yaitu dengan berkoordinasi dengan pihak kesehatan terutama puskesmas untuk evakuasi jika ada masyarakat yang harus dievakuasi. Sejalan dengan penelitian yang dilakukan di Kota Kendal didapatkan kesiapsiagaan keluarga untuk melakukan evakuasi mandiri secara keseluruhan dalam kategori baik. ${ }^{23}$ Berdasarkan Undang-Undang Nomor 24 Tahun 2007 tentang Penanggulangan Bencana, kelompok rentan meliputi: I). Bayi, balita dan anak-anak; 2). Ibu yang sedang mengandung atau menyusui; 3). Penyandang cacat; dan 4) Orang lanjut usia. Oleh sebab itu, kelompok rentan perlu diprioritaskan dalam penyelamatan, evakuasi, pengamanan hingga pelayanan kesehatan dan psikososial. ${ }^{24}$

Selama bencana banjir, rata-rata perilaku keluarga menggunakan air bersih untuk keperluan masak, dan keperluan MCK (Mandi, Cuci dan 
Kakus). Sebagian masyarakat masih menggunakan air banjir karna keterbatasan kecukupan air bersih selama banjir dan faktor ekonomi dalam membeli air bersih masih kurang. Sejalan dengan penelitian yang dilakukan di Desa Sitiarjo didapatkan bentuk adaptasi masyarakat dalam fase kesiapsiagaan bencana dibidang air bersih sudah berjalan dengan baik. Namun demikian masih terdapat kesenjangan karena perbedaan kemampuan ekonomi, terutama dalam menyediakan wadah yang cukup untuk persediaan air bersih dan air minum. ${ }^{25}$

Keterbatasan dalam berbagai hal dan fasilitas yang masih belum optimal selama banjir membuthkan kerjasama dari berbagai pihak terkait. Harapan pihak kepala desa secara umum dalam dalam upaya pencegahan dan penanggulangan dampak kesehatan akibat bencana banjirantara lain adalah kelengkapan sarana prasarana serta peningkatan layanan kesehatan. Masyarakat masih merasa kekurangan logistik atau sarana kesehatan ketika banjir dan penyediaan air bersih yang masih kurang.

\section{KESIMPULAN}

Hasil penelitian menunjukkan gambaran perilaku masyarakat di Desa Lubuk Siam masih belum ideal/optimal. Secara umum masyarakat sudah memahami kondisi banjir yang terjadi di desanya, baik dari penyebab dan dampaknya. Persiapan dalam menghadapi dampak kesehatan akibat bencana banjir masih kurang. Masyarakat masih kurang memahami mengenai penggunaan air bersih, persiapan obat obatan, $\mathrm{P} 3 \mathrm{~K}$ dan prosedur evakuasi. Secara tindakan, aktivitas masyarakat ketika banjir atau aktivitas dalam menghadapi banjir masih belum ideal. Banyak masyarakat yang menjadikan air banjir sebagai sarana mandi dan mencuci selama banjir. Kesiapan menghadapi banjir mulai dari obat obatan sebagai P3K, logistik, sarana evakuasi masih belum maksimal.

\section{DAFTAR PUSTAKA}

1. Badan Nasional Penanggulangan Bencana (BNPB). Buku saku tanggap tangkas tangguh menghadapi bencana. Jakarta: Pusat Data Informasi dan Humas Badan Nasional Penanggulangan Bencana; 2017:38.
2. Badan Nasional Penanggulangan Bencana (BNPB). Rencana nasional penanggulangan bencana 2015 - 2019. Jakarta; 2014:24

3. Mulyardi D. Analisis pengelolaan keuangan desa dalam pembangunan Desa Lubuk Siam Kecamatan Siak Hulu Kabupaten Kampar. [Skripsi] Universitas Islam Negeri Sultan Syarif Kasim Riau. 2017. Hal 50-1.

4. Widyatun W, Fatoni Z. Permasalahan kesehatan dalam kondisi bencana: peran petugas kesehatan dan partisipasi masyarakat. Jurnal Kependudukan Indonesia. 2016;8(1):37-52.

5. Purwarna R. Manajemen kedaruratan kesehatan lingkungan dalam kejadian bencana. Jakarta: Raja Grafindo Persada; 2013.

6. Amri MR, Yulianti G, Yunus R, Wiguna $\mathrm{S}$, Adi AW, Ichwana AN, et al. Risiko Bencana Indonesia(RBI). Jakarta: Direktorat Pengunrangan Risiko Bencana;2016.

7. Firmansyah I, Rasni H, Rondhianto. Hubungan pengetahuan dengan perilaku kesiapsiagaan dalam menghadapi bencana banjir dan longsor pada remaja usia 15-18 tahun di SMA Al- Hasan Kemiri Kecamatan Panti Kabupaten Jember. [Skripsi] 2014.

8. Umar N. Pengetahuan dan kesiapsiagaan masyarakat menghadapi bencana banjir di Bolapapu Kecamatan Kulawi Sigi Sulawesi Tengah. Jurnal Keperawatan Soedirman. 2013;8(3):188-190.

9. Kurniati E, Adriany V, Mirawati, Winangsih I, ElSiera RM. Pelatihan pengurangan risiko bencana bagi guru taman kanak-kanak di Kota Bandung. Jurnal Pendidikan Anak Usia Dini. 2020;11(1);19.

10. Notoatmodjo S. Ilmu perilaku kesehatan. Jakarta: Rineka Cipta;2010.

11. Akhirianto NA. Pengetahuan dan kesiapsiagaan masyarakat terhadap bencana banjir di Kota Bekasi (studi kasus: Perumahan Pondok Gede Permai). Jurnal Alami. 2018;2(1):72.

12. Lindawati, Wasludin. Hubungan pengetahuan dan sikap tentang bencana banjir terhadap kesiapsiagaan dalam kesehatan pada masyarakat RW 05 RT 01 dan RT 03 Kelurahan Gondrong 
Kota Tangerang. Jurnal Medikes (Media Informasi Kesehatan) Politeknik Kesehatan Kementerian Kesehatan Banten;4(2).

13. Widyatun W, Fatoni Z. Health problems in a disaster situation: The role of health personnels and community participation. Jurnal Kependudukan Indonesia. 2016;8(1):41.

14. Anwar A, dan Musadad A. Pengaruh akses penyediaan air bersih terhadap diare. Jurnal Ekologi Kesehatan. 2009;8(2).

15. Harthana T, Soedirham O. Faktor determinan perilaku cuci tangan pakai sabun saat banjir Bengawan Solo di Bojonegoro. Jurnal Promkes. 2014;2(2);160-172.

16. Razikin P, Kumalawati R, Arisanty D. Strategi penangulangan bencana banjir berdasarkan persepsi masyarakat di Kecamatan Barabai Kabupaten Hulu Sungai Tengah. JPG (Jurnal Pendidikan Geografi). 2017; 4(1);27-39.

17. Widayanti S Y M. Sikap sosial dan partisipasi masyarakat dalam penanggulangan bencana alam banjir. Jurnal PKS. 2016; 15(2);145 - 164.

18. Widya, Y., Suhartono \& Budiyanto. Resiliensi masyarakat dalam menghadapi banjir rob di Kelurahan Bandarharjo Kota Semarang (Studi Kasus Aspek Lingkungan dan Kesehatan). Review Literatur: Jurnal Kesehatan Masyarakat, 2018; 6(1);696-702.

19. Widayanto, Fatoni Z. Permasalahan kesehatan dalam kondisi bencana: Peran petugas kesehatan dan 20 partisipasi masyarakat. Review Literatur: Jurnal Pendidikan Indonesia, 2013; 8(1);37-52.
20. Zulqa I, Herawati R, \& Hardjanto US. Pelaksanaan tugas badan penanggulangan bencana daerah Kota Semarang berdasarkan peraturan daerah nomor 12 tahun 2010 tentang organisasi dan tata kerja badan penanggulangan bencana daerah Kota Semarang. Diponegoro Law Journal, 2017;6(4);1-16.

21. Kemenkes RI. (2018). Promosi kesehatan dalam bencana. Diakses pada 04 Juni 2021 dari: promkes.kemkes.go.id.

22. Ardiansyah Y, Rahmantari DN. Penyuluhan dan praktik PHBS (Perilaku Hidup Bersih dan Sehat) dalam mewujudkan masyarakat desa peduli sehat. Jurnal Inovasi dan Kewirausahaan, 2013; 2(1); 5-50.

23. Widiastuti YP, Darwati LE, Setianingsih. Identifikasi kesiapsiagaan keluarga melakukan evakuasi mandiri saat banjir. Jurnal Ilmiah Permas: Jurnal Ilmiah Stikes Kendal. 2021;11(1).

24. Badan Nasional Penanggulangan Bencana. Undang-Undang Nomor 24 Tahun 2007 tentang Penanggulangan Bencana. Jakarta: Badan Nasional Penanggulangan Bencana, 2007.

25. Suliono. Strategi Adaptasi Masyarakat Desa Sitiarjo Di Bidang Penyediaan Air Bersih Dan Sanitasi Dalam Menghadapi Dampak Kesehatan Akibat Bencana Banjir. Jurnal Kesehatan Lingkungan, 2018;10(4);351-9. 